\title{
Analisis Tingkat Pemahaman Guru Terhadap Konsep Pembelajaran Aritmatika-Bahasa di Sekolah Dasar
}

\author{
Eko Kuntarto* \\ Universitas Jambi, Kota Jambi, Jambi 36122, Indonesia \\ Pengiriman: 1 September 2018; Diterima: 29 September 2018; Publikasi: 30 September 2018 \\ DOI: https://doi.org/10.31629/jg.v3i2.629

\begin{abstract}
Abstrak
Penelitian ini bertujuan untuk mendeskripsikan tingkat pemahaman guru terhadap konsep pembelajaran aritmatika-bahasa. Populasi adalah guru sekolah dasar kelas I - III. Responden berjumlah 30 orang. Analisis dilakukan untuk menggambarkan: (1) tingkat pemahaman guru tentang kurikulum, (2) buku teks, (3) kurikulum pelatihan, dan (4) proses pembelajaran. Berdasarkan analisis data diketahui bahwa: (1) pemahaman terhadap kurikulum adalah yang paling tinggi sebesar 30,66\%; (2) buku pembelajaran sebesar 16,66\%; (3) kurikulum pelatihan 0,27\%; (4) proses pembelajaran 75,55\%. Analisis komponen Perencanaan Pendidikan (RPP) menghasilkan skor rata-rata $53,45 \%$ pada tingkat pemahaman guru, lebih kecil dari skor pedoman minimum $76 \%$. Berdasarkan pengamatan proses pembelajaran, diketahui bahwa hanya $23,22 \%$ responden atau 7 orang yang memperoleh skor baik. Itu artinya tingkat pemahaman tentang konsep pembelajaran aritmatika-bahasa relatif rendah. Dari hasil penelitian ini disajikan dengan saran-saran berikut: (1) harus ada langkah-langkah untuk meningkatkan pembelajaran elemen aritmatika-bahasa pemahaman guru, (2) kurikulum pelatihan harus menekankan pemahaman konseptual.
\end{abstract}

Kata kunci: pemahaman; guru aritmatika; kurikulum

\begin{abstract}
This study aimed to describe the level of teachers' understanding of the concept of arithmetic- language learning. The population was grade I - III of elementary school teacher. Respondents were 30 people. Analyzes were performed to describe: (1) the level of teachers' understanding of the curriculum, (2) textbooks, (3) training curriculum, and (4) the learning process. Based on data analysis, it is shown that: (1) understanding of the curriculum is the highest $30.66 \%$; (2) learning books is $16.66 \%$; (3) training curriculum is $0.27 \%$; (4) the learning process is $75.55 \%$. Analysis of the components of the Lesson Plan (RPP) yielded an average score of $53.45 \%$ level of understanding of teachers, smaller than the minimum guideline score $76 \%$. Based on the observation of the learning process, it is known that only $23.22 \%$ of respondents or 7 people who obtain a score well. That means that the level of understanding of the heritage of the concept of arithmetic-language learning is relatively low. From the results of this study, it is suggested that: (1) there should be measures to enhance learning of arithmeticlanguage element of understanding teachers, (2) training curriculum should emphasize conceptual understanding.
\end{abstract}

Keywords: comprehension; arithmetic teacher; curriculum

\section{Pendahuluan}

Kemampuan berbahasa tidak hanya mencakup kemampuan komunikasi, melainkan juga pola berpikir dan logika. Oleh karena itu,

*Penulis Korespondensi

Email Address: ekokuntarto@unja.ac.id

Handphone : : +62 81919142000 bahasa erat kaitannya dengan matematika dan statistika. Bahasa mengajarkan kemampuan komunikasi dan pola berpikir. Matematika menuntun pola pikir deduktif. Statistika menuntun 


\section{JURNAL GANTANG. September 2018; III(2): 97 - 108 \\ p-ISSN. 2503-0671 \\ e-ISSN. 2548-5547}

pola pikir induktif. Matematika adalah bahasa simbolis. Matematika menjembatani antara manusia dan alam, antara dunia batin dan dunia lahir. Matematika adalah alat pikiran, bahasa ilmu, tata cara pengetahuan, dan penyimpulan deduktif. Matematika adalah bahasa universal. (Kuntarto \& Asyhar, 2016).

Sementara logika adalah jendela bagi segala ilmu. Logika berperan dalam mengantarkan para ilmuwan untuk mendeseminasikan ilmunya kepada orang lain. Logika adalah filter bagi para ilmuwan untuk mengetahui validitas penalarannya. Namun, logika, matematika, dan statistika akan menjadi "barang mati” jika tidak ada bahasa. Bahasa adalah jembatan bagi ketiganya. Tanpa bahasa ilmu tidak akan berkembang. Tanpa bahasa tidak akan ada ilmuwan, dan orang-orang tidak akan bida belajar. Demikianlah, hubungan simbiosis mutualisme yang dibangun oleh bahasa, logika, matematika, dan statistika. (Kuntarto \& Asyhar, 2016).

Namun demikian, keempat bidang ilmu tersebut belum sepenuhnya dikuasai dan dimanfaatkan oleh anak-anak kita dalam mengembangkan kemampuan akademiknya. Pelajaran matematika, yang di dalamnya berisi logika dan statistika pada umumnya masih dianggap sulit oleh mereka. Sedangkan pelajaran bahasa, yang di dalamnya juga berisi logika, masih sebatas pelajaran menghafal gramatika. Bahasa belum menjadi alat penghela ilmu pengetahuan (Adriyani \& Kuntarto, 2017).

Meskipun kemampuan membaca, menulis, dan sains menjadi fondasi bagi pengembangan kehidupan masyarakat mulai tingkat sosial yang paling bawah sampai tingkat tertinggi, namun penguasaan ketiga bidang tersebut di Indonesia termasuk kategori paling bawah di antara negara-negara lain di dunia. Hasil studi internasional Programme for International Student Assessment (PISA) dan Trends in International Mathematics and Science Study (TIMSS), yang mengukur kemampuan menulis, membaca, dan sains menunjukkan bahwa siswa di Indonesia memiliki kemampuan yang rendah pada ketiga aspek tersebut. Menurut hasil studi TIMSS, kemampuan siswa Indonesia pada aspek membaca, menulis dan sains menempati peringkat ke-68 dari 74 negara dengan nilai rata-rata 371. Berdasarkan pemeringkatan itu, Indonesia masuk pada kategor Low International Brenchmark (Kuntarto \& Asyhar, 2016). Rendahnya peringkat tersebut menunjukkan bahwa proses pembelajaran membaca, menulis, sains di sekolah-sekolah Indonesia belum benar-benar sesuai dengan harapan. Sementara menurut hasil survei PISA pada 2015, dari 65 negara yang disurvei, kualitas pendidikan di Indonesia berada pada posisi 5 paling bawah dalam daftar 65 negara responden. Kualitas pendidikan tersebut ditentukan dengan hasil pembelajaran membaca, menulis, sains dan berhitung di setiap jenjang pendidikan (Kuntarto \& Destrinelli, 2014)

Kurikulum 2013 di SD Kelas Rendah mengedepankan penguatan keterampilan aritmatika-bahasa yang diberi label pembelajaran membaca, menulis, dan berhitung (calistung). Hal itu tentunya dilandasi oleh kesadaran bahwa kemampuan tersebut menjadi fondasi bagi pengembangan kehidupan masyarakat. Keberhasilan implementasi Kurikulum 2013 dalam kegiatan pembelajaran di kelas-kelas sekolah dasar sangat ditentukan oleh kualitas pendidik, utamanya dalam memahami konsepkonsep pembelajaran. Kurikulum 2013 mempunyai karakter berorientasi pada tujuan dan fokus pada proses, sehingga bisa menghasilkan sebuah sistem pendidikan yang tepat guna dan efektif. Dari rancangan karakter kurikulum di atas mestinya mutu guru menjadi faktor penting dalam menyukseskan pelaksanaannya.

Akan tetapi, beberapa penelitian menemukan bukti bahwa pemahaman guru terhadap konsep pembelajaran aritmatika-bahasa masih rendah. Dalam penelitian di sejumlah SD Negeri dan SD Swasta di Kota Jambi, hasil pembelajaran aritmatika-bahasa rata-rata 55, sehingga belum memenuhi Kriteria Ketuntasan Minimal (KKM) yang telah ditetapkan 
sebelumnya, yakni 70. Banyak hal yang melatarbelakangi hal tersebut, antara lain kemungkinan tentang rendahnya pemahaman guru SD terhadap konsepsi pembelajaran aritmatika-bahasa. Kondisi tersebut dipandang ideal bagi sasaran penelitian. (Wardhani, Hasyim, \& Rosidin, 2015).

Kajian teoretis terhadap buku ajar untuk SD Kelas I memberi simpulan bahwa keterampilan aritmatika-bahasa yang terdiri atas membaca, menulis, dan berhitung tidak akan tumbuh secara maksimal. Hal ini akan terjadi juga pada kelas II dan III, mengingat bahwa di kelas-kelas tersebut sudah ditetapkan seluruh tema dan sudah dilengkapi seluruh kompetensi dasar. Ini berarti bahwa pembentukan keterampilan aritmatika-bahasa, yang terdiri atas keterampilan membaca, menulis, dan berhitung di kelas-kelas tersebut juga tidak maksimal. (Kuntarto, 2013).

Oleh karena itu, agar implementasi Kurikulum 2013 dapat menumbuhkan keterampilan membaca, menulis, dan berhitung secara maksimal perlu adanya penguatan. Penguatan tersebut diwujudkan dalam bentuk menanamkan pemahaman terhadap guru tentang materi dan model pembelajaran yang sesuai, serta konsepsi filosofis dan empiris tentang pembelajaran aritmatika-bahasa yang selaras dengan capaian pembelajaran yang telah ditetapkan dalam kurikulum. Guru juga perlu memahami dengan baik model pembelajaran di dalamnya mencakup pendekatan, metode, strategi, dan teknik yang selaras dengan kebutuhan. Sementara pemahaman filosofis dan empiris akan mengantarkan guru dalam menyiapkan, melaksanakan, dan menilai hasil belajar secara arif (Maryeni; Rochmiyati; Sasmiati, 2014; Wardhani et al., 2015).

Persoalan mendasar yang ada dalam penerapan Kurikulum 2013 pada pembelajaran Aritmatika-Bahasa adalah kenyataan bahwa tidak semua materi yang mendukung suatu kompetensi dalam matematika dapat dengan mudah diintegrasikan dalam suatu tema yang mengintegrasikan beberapa mata pelajaran.
Setiap tema dalam buku ajar untuk SD Kelas I memadukan berbagai mata pelajaran, termasuk Bahasa Indonesia dan Matematika. Kajian teoretis terhadap buku ajar untuk SD Kelas I - III memberi simpulan bahwa keterampilan membaca, menulis, dan berhitung tidak akan tumbuh secara maksimal. Agar implementasi Kurikulum 2013 dapat menumbuhkan keterampilan aritmatika-bahasa yang terdiri atas kemampuan membaca, menulis, dan berhitung secara maksimal perlu adanya penguatan. (Kuntarto \& Destrinelli, 2014).

Persoalan lain yang tidak kalah penting adalah bahwa perubahan kurikulum selalu membutuhkan penyesuaian pola pikir para pemangku kepentingan (stake holder). Demikian pula yang terjadi pada Kurikulum 2013 ini. Ia hanya mungkin sukses bila ada perubahan paradigma atau lebih tepatnya mindset para guru dalam proses pembelajaran. Pemahaman guru terhadap konsep pembelajaran harus berada pada kategori baik. Tingkat pemahaman konsep berkaitan dengan kemampuan seseorang dalam memahami secara komprehensif ide atau gagasan, prosedur, dan fakta yang membentuk sebuah jaringan berfikir dengan keterkaitan yang tinggi. Sementara konsep dimaknai sebagai ide abstrak yang dapat digunakan untuk mengelompokkan, mengklasifikasikan, dan mengkategorikan sekumpulan objek dalam satu kesatuan yang padu dan bermakna (Ayuni, 2015).

Pemahaman guru terhadap konsep pembelajaran aritmatika-bahasa mencakup kemampuan untuk: (1) mengungkapkan kembali apa yang telah dikomunikasikan kepadanya, (2) menggunakan konsep pada berbagai kondisi dan situasi yang berbeda, dan (3) mengembangkan rangkaian sebab-akibat dari suatu konsep, sehingga menjadi solusi untuk menyelesaikan setiap masalah dengan benar. Pemahaman konsep merupakan salah satu kecakapan atau kemahiran yang diharapkan dapat dikuasai oleh guru agar tepat dalam melakukan pemecahan masalah (Zamzami \& Yuniarni, n.d.).

Ada dua jenis pemahaman konsep, yaitu 


\section{JURNAL GANTANG. September 2018; III(2): 97 - 108 \\ p-ISSN. 2503-0671 \\ e-ISSN. 2548-5547}

pemahaman instrumental dan pemahaman rasional. Pemahaman instrumental adalah pemahaman atas konsep yang saling terpisah; sedangkan pemahaman rasional mencakup kemampuan untuk menyusun skema atau struktur yang digunakan untuk menyelesaikan masalah yang lebih luas. Ide, prosedur, fakta dapat dipahami sepenuhnya jika ketiganya saling dikaitkan dengan jejaring yang bersifat interkoneksi. Agar dapat dicapai pemahaman yang bermakna atas ide, prosedur, maupun fakta, maka guru harus menampilkan pembelajaran yang diarahkan pada pengembangan kemampuan interkoneksi antara berbagai ide atau gagasan, prosedur, maupun fakta dalam konteks di luar materi pembelajaran itu sendiri (Harsono, 2005).

Berdasarkan latar belakang, aspek pemahaman guru terhadap pembelajaran aritmatika-bahasa di SD perlu dikaji lebih mendalam. Penelitian tentang pemahaman guru terhadap konsepsi pembelajaran aritmatikabahasa di SD kelas rendah (kelas I-III) perlu dilakukan. Kajian tentang pemahaman konsep pembelajaran tidak hanya menyangkut pemahaman teoretis, yang dapat diungkap melalui asesmen pengetahuan. Aspek pemahaman konsep juga dapat diketahui melalui perencanaan dan implementasi pada tataran praktis yang dapat diamati ketika guru yang bersangkutan mempersiapan diri dan mengajar di depan kelas.

\section{Metode Penelitian}

Penelitian ini menggunakan desain Sequential Explanatory. Ciri khas desain Sequential Explonatory adalah pada tahap pertama dilakukan pengumpulan dan analisis data secara kuantitatif, dan pada tahap kedua dilakukan pengumpulan dan analisis data secara kualitatif. Metode kualitatif digunakan untuk memperkuat analisis.

Populasi penelitian ini adalah 250 orang guru SD kelas I, II, dan III. Responden penelitian sebanyak 30 orang yang dipilih secara acak. Data dikumpulkan menggunakan angket, analisis komponen, observasi, dan wawancara.

Pada tahap awal, analisis data dilakukan dengan menghitung skor dan persentase berdasarkan data yang diperoleh melalui angket. Selanjutnya dilakukan analisis data kualitatif melalui pemahaman atau interpretasi terhadap skor. Analisis interpretasi tersebut dilakukan untuk melengkapi deskripsi data kuantitatif dengan tujuan membuktikan, memperdalam, dan memperluas pemahaman terhadap data. Untuk itu digunakan uraian atau deskripsi sistematis menggunakan kata-kata.

Selanjutnya, analisis data dilakukan secara kualitatif dengan mengorganisasikan data, memilah-milahnya menjadi satuan yang dapat dikelola, mensintesiskannya, mencari dan menemukan pola, menemukan apa yang penting dipelajari dan memutuskan apa yang dapat diceritakan kepada orang lain.

\section{Hasil dan Pembahasan}

Berdasarkan analisis data yang diperoleh melalui angket tersebut diketahui bahwa jumlah responden yang pemahaman konseptualnya pada tingkat rendah sebanyak 32,24\%; pada tingkat cukup sebanyak $18,85 \%$; pada tingkat sedang sebanyak 13,42\%; dan pada tingkat tinggi sebanyak $35,35 \%$. Tingkat pemahaman guru terhadap konsep pembelajaran aritmatika-bahasa tergambar pada gambar 1 berikut (dengan persentase dibulatkan).

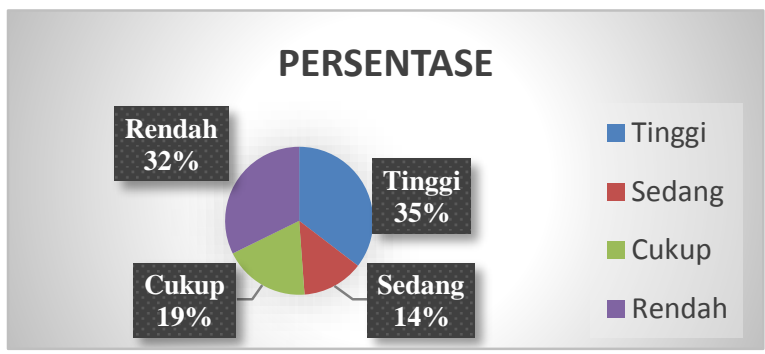

Gambar 1. Tingkat Pemahaman Responden

Hasil analisis terhadap masing-masing aspek yang diteliti dapat disampaikan sebagai berikut. Pada aspek (A) Pemahaman terhadap Kurikulum 2013, diketahui bahwa 16,6\% responden memiliki tingkat pemahaman rendah, $22,67 \%$ memiliki tingkat pemahaman cukup, $30 \%$ memiliki tingkat pemahaman sedang, dan hanya $30,66 \%$ yang memiliki tingkat pemahaman tinggi. Data selengkapnya dapat 
dilihat pada tabel 1 berikut.

Tabel 1.

Hasil analisis tingkat pemahaman responden terhadap kurikulum

\begin{tabular}{|c|c|c|c|c|c|c|}
\hline \multirow{2}{*}{ Aspek } & \multirow{2}{*}{ Pertanyaan } & \multicolumn{5}{|c|}{ Skor Butir } \\
\hline & & 1 & 2 & 3 & 4 & $\sum$ \\
\hline \multirow[t]{5}{*}{$\begin{array}{l}\text { A. Pendapat Terhadap } \\
\text { Kurikulum }\end{array}$} & $\begin{array}{l}\text { Bagaimana pemahaman } \\
\text { Bapak/ibu terhadap } \\
\text { tujuan kurikulum } 2013 ?\end{array}$ & 8 & 5 & 10 & 7 & 30 \\
\hline & $\begin{array}{l}\text { Bagaimana pemahaman } \\
\text { Bapak/Ibu terhadap } \\
\text { pendekatan tematik } \\
\text { terpadu? }\end{array}$ & 2 & 10 & 8 & 10 & 30 \\
\hline & $\begin{array}{l}\text { Bagaimana pemahaman } \\
\text { Bapak/Ibu terhadap } \\
\text { pendekatan saintifik? }\end{array}$ & 5 & 4 & 10 & 11 & 30 \\
\hline & $\begin{array}{l}\text { Pandangan Anda terhadap } \\
\text { pelaksanaan pembelajaran } \\
\text { Calistung berdasarkan } \\
\text { kurikulum } 2013\end{array}$ & 7 & 8 & 7 & 8 & 30 \\
\hline & $\begin{array}{l}\text { Pendapat Anda terhadap } \\
\text { ketersediaan buku Teks } \\
\text { untuk Siswa dan Buku } \\
\text { Pedoman Guru untuk } \\
\text { pembelajaran Calistung? }\end{array}$ & 3 & 7 & 10 & 10 & 30 \\
\hline \multicolumn{2}{|c|}{ Jumlah Respon Per Butir Angket (n) } & 25 & 34 & 45 & 46 & \\
\hline \multicolumn{2}{|c|}{ Jumlah Respon (R) } & & & & & 150 \\
\hline \multicolumn{2}{|c|}{ Persentase Pemahaman Per Kategori (n:R/100) } & 16,66 & 22,67 & 30 & 30,66 & 99,99 \\
\hline
\end{tabular}

Selanjutnya dapat dilihat tingkat pemahaman responden terhadap aspek buku pelajaran aritmatika-bahasa (aspek B). Berdasarkan tabel di bawah diketahui bahwa dari 30 responden,
29,25\% memiliki tingkat pemahaman rendah, $31,85 \%$ memiliki tingkat pemahaman cukup, $22,22 \%$ memiliki tingkat pemahaman sedang, dan 16,66\% memiliki tingkat pemahaman tinggi.

Tabel 2.

Hasil analisis tingkat pemahaman responden terhadap buku teks

\begin{tabular}{|c|c|c|c|c|c|c|}
\hline \multirow{2}{*}{ Aspek } & \multirow{2}{*}{ Pertanyaan } & \multicolumn{5}{|c|}{ Skor Butir } \\
\hline & & 1 & 2 & 3 & 4 & $\sum$ \\
\hline \multirow{14}{*}{$\begin{array}{l}\text { B. Pendapat } \\
\text { Terhadap Buku } \\
\text { Teks Pembelajaran } \\
\text { 1. Buku Siswa }\end{array}$} & Apakah isi buku teks & \multirow[t]{7}{*}{6} & \multirow[t]{7}{*}{8} & \multirow[t]{7}{*}{8} & \multirow[t]{7}{*}{8} & \multirow[t]{7}{*}{30} \\
\hline & \multirow{6}{*}{$\begin{array}{l}\text { Pembelajaran Calistung } \\
\text { mengurai atau memerinci } \\
\text { tuntutan ranah kompetensi } \\
\text { sikap, pengetahuan, dan } \\
\text { ketrampilan yang tertulis } \\
\text { dalam dokumen kurikulum } \\
2013 \text { ? }\end{array}$} & & & & & \\
\hline & & & & & & \\
\hline & & & & & & \\
\hline & & & & & & \\
\hline & & & & & & \\
\hline & & & & & & \\
\hline & Apakah contoh-contoh & & 12 & \multirow[t]{4}{*}{5} & \multirow[t]{4}{*}{3} & \multirow[t]{4}{*}{30} \\
\hline & kegiatan yang ada dalam buku & \multirow{3}{*}{10} & & & & \\
\hline & teks Calistung dapat dengan & & & & & \\
\hline & mudah dilakukan oleh murid? & & & & & \\
\hline & Bagaimana pendapat & \multirow[t]{3}{*}{8} & \multirow[t]{3}{*}{12} & \multirow[t]{3}{*}{5} & \multirow[t]{3}{*}{5} & \multirow[t]{3}{*}{30} \\
\hline & Bapak/Ibu terhadap ilustrasi & & & & & \\
\hline & (gambar) dalam buku teks & & & & & \\
\hline
\end{tabular}


JURNAL GANTANG. September 2018; III(2): 97 - 108

Pembelajaran Calistung?

\begin{tabular}{|c|c|c|c|c|c|c|}
\hline & $\begin{array}{l}\text { Bagaimana pendapat } \\
\text { Bapak/Ibu terhadap } \\
\text { penggunaan bahasa dalam } \\
\text { buku teks Pembelajaran } \\
\text { Calistung? }\end{array}$ & 8 & 12 & 6 & 4 & 30 \\
\hline & $\begin{array}{l}\text { Apakah buku yang tersedia } \\
\text { dapat meningkatkan } \\
\text { efektivitas proses } \\
\text { pembelajaran? }\end{array}$ & 12 & 12 & 3 & 3 & 30 \\
\hline \multirow[t]{4}{*}{ 2.Buku Guru } & $\begin{array}{l}\text { Apakah buku pedoman guru } \\
\text { dapat membantu Bapak/Ibu } \\
\text { dalam merencanakan proses } \\
\text { pembelajaran? }\end{array}$ & 5 & 4 & 10 & 11 & 30 \\
\hline & $\begin{array}{l}\text { Apakah buku pedoman guru } \\
\text { memberikan panduan yang } \\
\text { jelas tentang penerapan } \\
\text { pembelajaran Calistung? }\end{array}$ & 10 & 12 & 6 & 2 & 30 \\
\hline & $\begin{array}{l}\text { Apakah buku pedoman guru } \\
\text { memberikan panduan yang } \\
\text { jelas tentang penerapan } \\
\text { penilaian? }\end{array}$ & 5 & 9 & 12 & 4 & 30 \\
\hline & $\begin{array}{l}\text { Menurut pandangan } \\
\text { Bapak/Ibu, apakah buku } \\
\text { pedoman guru membantu } \\
\text { meningkatkan efektivitas } \\
\text { proses pembelajaran } \\
\text { Calistung? }\end{array}$ & 15 & 5 & 5 & 5 & 30 \\
\hline \multicolumn{2}{|c|}{ Jumlah Respon Per Butir Angket (n) } & 79 & 86 & 60 & 45 & \\
\hline \multicolumn{2}{|c|}{ Jumlah Respon (R) } & & & & & 270 \\
\hline \multicolumn{2}{|c|}{ Persentase Pemahaman Per Kategori (n:R/100) } & 29,25 & 31,85 & 22,22 & 16,66 & 99,98 \\
\hline
\end{tabular}

Selanjutnya dapat dilihat tingkat pemahaman guru berdasarkan pengetahuannya tentang kurikulum pembelajaran calistung yang diperoleh melalui pelatihan (aspek C). Berdasarkan data pada Tabel 10 berikut diketahui bahwa dari 30 orang responden, $58,37 \%$ memiliki tingkat pemahaman rendah, $20,27 \%$ memiliki tingkat pemahaman cukup, $11,08 \%$ memiliki tingkat pemahaman sedang, dan 10,27\% memiliki tingkat pemahaman tinggi.

Tabel 3.

Hasil analisis tingkat pemahaman responden terhadap materi pelatihan kurikulum

\begin{tabular}{|c|c|c|c|c|c|c|}
\hline \multirow{2}{*}{ Aspek } & \multirow{2}{*}{ Pertanyaan } & \multicolumn{5}{|c|}{ Skor Butir } \\
\hline & & 1 & 2 & 3 & 4 & $\sum$ \\
\hline \multirow[t]{2}{*}{$\begin{array}{l}\text { C. Pemahaman } \\
\text { terhadap Materi } \\
\text { Pelatihan Kurikulum } \\
2013\end{array}$} & $\begin{array}{l}\text { Apakah materi pelatihan } \\
\text { sesuai dengan kebutuhan } \\
\text { pembelajaran Calistung } \\
\text { dalam Kurikulum 2013? }\end{array}$ & 17 & 2 & 6 & 5 & 30 \\
\hline & $\begin{array}{l}\text { Apakah materi pelatihan } \\
\text { telah mencakup seluruh } \\
\text { standar proses, yaitu proses } \\
\text { perencanaan, pelaksanaan, } \\
\text { penilaian dan pengawasan } \\
\text { proses pembelajaran } \\
\text { Calistung? }\end{array}$ & 10 & 15 & 5 & 0 & 30 \\
\hline
\end{tabular}


Kuntarto: Analisis Tingkat Pemahaman Guru...(12)

\begin{tabular}{|c|c|c|c|c|c|c|}
\hline & $\begin{array}{l}\text { Apakah materi pelatihan } \\
\text { pembelajaran Calistung } \\
\text { telah mencakup standar } \\
\text { kompetensi lulusan? }\end{array}$ & 17 & 3 & 5 & 5 & 30 \\
\hline & $\begin{array}{l}\text { Apakah materi pelatihan } \\
\text { pembelajaran Calistung } \\
\text { relevan dalam mengubah } \\
\text { pola pikir (mindset) siswa? }\end{array}$ & 10 & 12 & 5 & 3 & 30 \\
\hline & $\begin{array}{l}\text { Apakah materi pelatihan } \\
\text { memuat hal-hal baru } \\
\text { (termasuk metode) dalam } \\
\text { pembelajaran Calistung? }\end{array}$ & 22 & 0 & 4 & 4 & 30 \\
\hline & $\begin{array}{l}\text { Apakah konsep pendekatan } \\
\text { saintifik tersampaikan } \\
\text { dengan baik dalam } \\
\text { pelatihan pembelajaran } \\
\text { Calistung? }\end{array}$ & 25 & 1 & 1 & 3 & 30 \\
\hline & $\begin{array}{l}\text { Apakah konsep pendekatan } \\
\text { saintifik tersampaikan } \\
\text { dengan baik dalam } \\
\text { pelatihan pembelajaran } \\
\text { Calistung? }\end{array}$ & 25 & 1 & 1 & 3 & 30 \\
\hline & $\begin{array}{l}\text { Apakah contoh pendekatan } \\
\text { saintifik yang disampaikan } \\
\text { dalam pelatihan } \\
\text { pembelajaran calistung } \\
\text { cukup jelas dalam } \\
\text { menjelaskan konsep? }\end{array}$ & 27 & 1 & 1 & 1 & 30 \\
\hline & $\begin{array}{l}\text { Apakah konsep } \\
\text { pembelajaran calistung } \\
\text { sebagai pembelajaran } \\
\text { terpadu telah tersampaikan } \\
\text { dengan baik dalam } \\
\text { pelatihan? }\end{array}$ & 19 & 6 & 5 & 5 & 35 \\
\hline & $\begin{array}{l}\text { Apakah hasil pelatihan } \\
\text { pembelajaran calistung } \\
\text { berimplikasi terhadap } \\
\text { pembelajaran di sekolah } \\
\text { Anda? }\end{array}$ & 13 & 12 & 2 & 3 & 30 \\
\hline & $\begin{array}{l}\text { Apakah contoh } \\
\text { pembelajaran terpadu yang } \\
\text { mengintegrasikan } \\
\text { penyampaian materi } \\
\text { membaca, menulis, dan } \\
\text { berhitung telah } \\
\text { tersampaikan cukup jelas? }\end{array}$ & 23 & 5 & 1 & 1 & 30 \\
\hline & $\begin{array}{l}\text { Setelah mengikuti } \\
\text { pelatihan, apakah } \\
\text { Bapak/Ibu memperoleh } \\
\text { gambaran yang jelas } \\
\text { bagaimana melaksanakan } \\
\text { proses pembelajaran } \\
\text { calistung sesuai dengan } \\
\text { Kurikulum 2013? }\end{array}$ & 8 & 17 & 5 & 5 & 35 \\
\hline Jumlah Respon Per Butir & Angket (n) & 216 & 75 & 41 & 38 & \\
\hline Jumlah Respon (R) & & & & & & 370 \\
\hline Persentase Jawaban Per K & Kategori (n:R/100) & 58,37 & 20,27 & 11,08 & 10,27 & 99,99 \\
\hline
\end{tabular}


JURNAL GANTANG. September 2018; III(2): 97 - 108

p-ISSN. 2503-0671

e-ISSN. 2548-5547

Tingkat pemahaman guru terhadap aspek proses pembelajaran (aspek D), yang di dalamnya mencakup perencanaan dan pelaksanaan, telah baik. Guru yang memiliki pemahaman rendah berjumlah 20,55\%, pemahaman cukup 3,05\%, pemahaman sedang $0,83 \%$, dan pemahaman $75,55 \%$. Data selengkapnya tercantum pada Tabel 11 berikut.

Tabel 4 .

Hasil analisis tingkat pemahaman responden terhadap proses pembelajaran

\begin{tabular}{|c|c|c|c|c|c|c|}
\hline \multirow{2}{*}{ Aspek } & \multirow{2}{*}{ Pertanyaan } & \multicolumn{5}{|c|}{ Skor Butir } \\
\hline & & 1 & 2 & 3 & 4 & $\sum$ \\
\hline \multirow[t]{2}{*}{$\begin{array}{l}\text { D. Proses Pembelajaran } \\
\text { 1.Perencanaan }\end{array}$} & $\begin{array}{l}\text { Apakah Bapak/Ibu } \\
\text { membuat RPP sebelum } \\
\text { mengajar? }\end{array}$ & 0 & 0 & 0 & 30 & 30 \\
\hline & $\begin{array}{l}\text { Apakah Bapak/Ibu paham } \\
\text { tentang komponen RPP } \\
\text { pembelajaran calistung } \\
\text { sesuai dengan kurikulum } \\
2013 ?\end{array}$ & 0 & 0 & 0 & 30 & 30 \\
\hline \multirow[t]{8}{*}{ 2.Pelaksanaan } & $\begin{array}{l}\text { Apakah Bapak/Ibu, } \\
\text { mampu melakukan proses } \\
\text { pembelajaran caslitung } \\
\text { menggunakan pendekatan } \\
\text { tematik? }\end{array}$ & 0 & 0 & 0 & 30 & 30 \\
\hline & $\begin{array}{l}\text { Apakah Bapak/ibu, } \\
\text { memahami dengan baik } \\
\text { langkah-langkah } \\
\text { pembelajaran calistung? }\end{array}$ & 0 & 0 & 0 & 30 & 30 \\
\hline & $\begin{array}{l}\text { Apakah Bapak/Ibu, mampu } \\
\text { menyiapkan media } \\
\text { pembelajaran calistung? }\end{array}$ & 0 & 0 & 0 & 30 & 30 \\
\hline & $\begin{array}{l}\text { Apakah siswa mampu } \\
\text { mengikuti proses } \\
\text { pembelajaran calistung? }\end{array}$ & 0 & 0 & 0 & 30 & 30 \\
\hline & $\begin{array}{l}\text { Apakah Bapak/ibu, mampu } \\
\text { melakukan proses } \\
\text { pembelajaran calistung } \\
\text { yang membuat murid } \\
\text { menjadi lebih sering } \\
\text { bertanya? }\end{array}$ & 0 & 0 & 0 & 30 & 30 \\
\hline & $\begin{array}{l}\text { Apakah Bapak/Ibu, mampu } \\
\text { melakukan proses } \\
\text { pembelajaran calistung } \\
\text { yang membuat murid } \\
\text { menjadi lebih berani } \\
\text { mengemukan pendapat? }\end{array}$ & 22 & 8 & 0 & 0 & 30 \\
\hline & $\begin{array}{l}\text { Apakah Bapak/Ibu, } \\
\text { mampu melakukan proses } \\
\text { pembelajaran yang } \\
\text { membuat murid memiliki } \\
\text { sikap ilmiah? }\end{array}$ & 27 & 1 & 1 & 1 & 30 \\
\hline & $\begin{array}{l}\text { Apakah Bapak/Ibu, } \\
\text { mampu untuk melakukan } \\
\text { proses pembelajaran yang } \\
\text { menumbuhkan kreatifitas } \\
\text { murid? }\end{array}$ & 25 & 2 & 2 & 1 & 30 \\
\hline
\end{tabular}


Kuntarto: Analisis Tingkat Pemahaman Guru...(12)

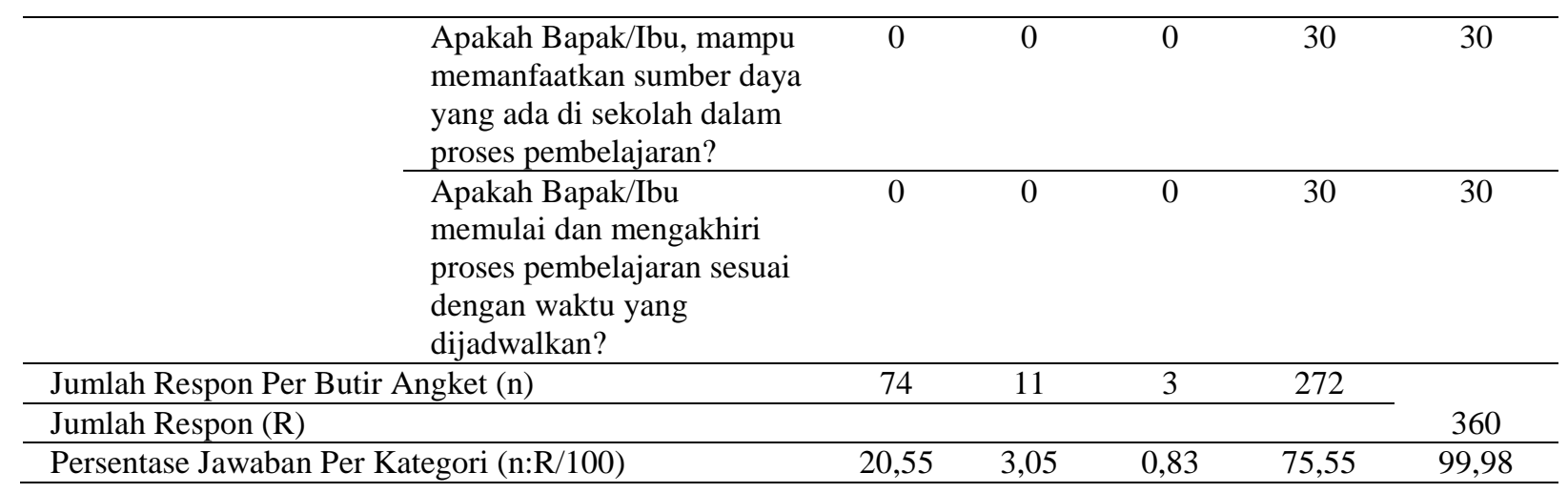

Berdasarkan hasil angket diketahui hanya aspek proses pembelajaran (aspek D) yang memiliki tingkat pemahaman tinggi, yakni $75,55 \%$. Selebihnya, pemahaman guru terhadap aspek A kategori tertinggi $16,66 \%$, aspek $\mathrm{B}$ kategori tertinggi $16,66 \%$, dan aspek $\mathrm{C}$ kategori tertinggi $10,27 \%$. Namun demikian, tingkat pemahaman pada aspek D perlu divalidasi melalui observasi agar diketahui relevansi antara pengetahuan teoretis dan praktik di lapangan. Deskripsi tentang tingkat pemahaman guru terhadap ke empat aspek tersebut dapat tergambar pada gambar 2 berikut.

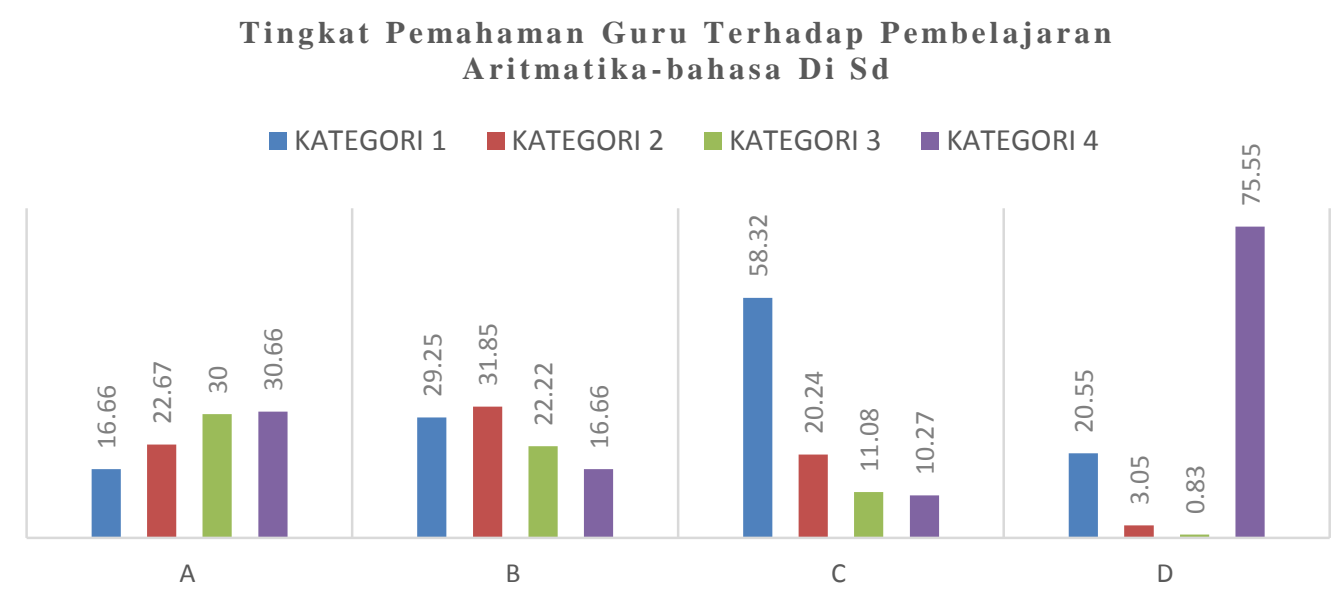

Gambar 2. Tingkat pemahaman guru pada 4 aspek yang diteliti

Data pada grafik 2 tersebut dapat dijelaskan sebagai berikut. Aspek A (pemahaman terhadap kurikulum), tingkat pemahaman guru paling tinggi 30,66\%. Aspek B (pemahaman terhadap buku pembelajaran), tingkat pemahaman guru paling tinggi $16,66 \%$. Aspek C (pemahaman terhadap materi pelatihan kurikulum), tingkat pemahaman paling tinggi $10,27 \%$. Aspek D (pemahaman terhadap proses pembelajaran), tingkat pemahaman paling tinggi $75,55 \%$.

Dengan demikian, tingkat pemahaman guru yang paling rendah ada pada aspek $\mathrm{C}$ (pemahaman terhadap materi pelatihan kurikulum), yakni 10,27\%. Hal ini berarti, pemahaman guru lemah pada materi pelatihan Kurikulum 2013. Implikasi kelemahan tingkat pemahaman tersebut akan berdampak pada pelaksanaan pembelajaran di kelas karena kegiatan pembelajaran selalu merujuk pada kurikulum. Namun demikian, perlu dilakukan langkah-langkah validasi terhadap fenomena tersebut melalui pengumpulan data kualitatif dengan metode wawancara, pengamatan, dan analis dokumen.

Penilaian terhadap dokumen RPP 
JURNAL GANTANG. September 2018; III(2): 97 - 108

p-ISSN. 2503-0671

e-ISSN. 2548-5547

dilakukan terhadap RPP yang dibuat oleh 30 orang responden, dengan menggunakan analisis komponen. Analisis komponen RPP dilakukan terhadap para responden yang terdiri atas guru kelas I, II, dan III SD. Analisis dilaksanakan pada 3 buah RPP yang disusun guru untuk pembelajaran minggu ke-1, ke-2, dan ke-3. Ke tiga buah RPP tersebut masing-masing untuk

kelas I, kelas II, dan kelas III dianalisis. RPP 1 adalah RPP yang disusun oleh 10 orang guru kelas I. RPP 2 adalah RPP yang disusun oleh 10 orang guru kelas II; sedangkan RPP 3 adalah RPP yang disusun oleh 10 orang guru kelas III. Dengan demikian total ada 30 RPP $\times 3$ kelas = 90 RPP. Hasil analisis dapat diamati pada tabel di berikut.

Tabel 5.

Hasil Analisis terhadap RPP yang disusun responden

\begin{tabular}{|c|c|c|c|c|c|c|}
\hline \multirow{2}{*}{ No } & \multirow{2}{*}{ Komponen } & \multicolumn{3}{|c|}{ Rata-rata Skor } & \multirow{2}{*}{ Rata-rata } & \multirow{2}{*}{ Keterangan } \\
\hline & & RPP 1 & RPP 2 & RPP 3 & & \\
\hline 1 & Identitas Mata Pelajaran/Tema & 100 & 100 & 100 & 100 & SB \\
\hline 2 & Indikator & 75 & 75 & 75 & 75 & $\mathrm{~B}$ \\
\hline 3 & Materi Ajar & 58 & 58 & 58 & 58 & $\mathrm{~B}$ \\
\hline 4 & Sumber Belajar & 83 & 91 & 83 & 85,6 & SB \\
\hline 5 & Media Pembelajaran & 75 & 75 & 75 & 75 & $\mathrm{~B}$ \\
\hline 6 & Kegiatan Pembelajaran & 75 & 75 & 75 & 75 & $\mathrm{~B}$ \\
\hline 7 & Penilaian & 81 & 81 & 81 & 81 & SB \\
\hline \multicolumn{2}{|c|}{ Jumlah Skor } & 51.7 & 55.5 & 51.7 & 549,6 & \\
\hline \multicolumn{2}{|c|}{ Rata-rata Skor } & 51.7 & 55.5 & 51.7 & 54,9 & $\mathrm{~B}$ \\
\hline \multicolumn{6}{|c|}{ Skor Rata-rata untuk seluruh RPP dan responden } & 53,45 \\
\hline
\end{tabular}

Berdasarkan hasil analisis diketahui bahwa nilai rata-rata untuk RPP guru kelas I adalah 51.7. Nilai rata-rata untuk guru kelas II adalah 55.5. Nilai rata-rata untuk guru kelas III adalah 51.7. Dengan demikian nilai rata-rata untuk seluruh RPP adalah 53.45.

Jika nilai tersebut dirujuk dengan tabel rujukan, maka pemahaman guru terhadap pembelajaran aritmatika-bahasa pada aspek Perencanaan Pembelajaran yang tergambar pada dokumen RPP, pada kategori Sedang (S).

Tabel 6.

Interval dan kategorisasi

\begin{tabular}{|l|l|}
\hline Interval Skor/Persentase & \multicolumn{1}{|c|}{ Kategori } \\
\hline $76-100$ & Baik \\
\hline $51-75$ & Sedang \\
\hline $26-50$ & Cukup (C) \\
\hline$<26$ & Kurang (K) \\
\hline
\end{tabular}

Hasil observasi menunjukkan bahwa rata-rata pemahaman guru terhadap pembelajaran aritmatika-bahasa pada tataran implementasi yang meliputi aspek, (1) Kesesuaian pelaksanaan dengan konsep pembelajaran Aritmatika-Bahasa, (2) Kesesuaian pembelajaran dengan RPP, (3) Prosedur pelaksanaan pembelajaran AritmatikaBahasa, dan (4) Prosedur evaluasi pembelajaran Aritmatika-Bahasa berada pada skor $23,22 \%$ jauh dari indikator minimal pemahaman yang ditetapkan sebesar 76\%. Hasil ini menunjukkan bahwa pemahaman guru pada tataran teoretis gayut dengan pemahaman guru pada tataran praktis. Jika pemahaman teoretis guru rendah, maka pada praktik pembelajaran juga rendah. Hasil analisis ini sekaligus mengoreksi hasil angket pada aspek D (Pemahaman terhadap Proses Pembelajaran) yang menghasilkan skor rata-rata $75,55 \%$. Hasil penelitian ini mendukung temuan penelitian yang dilakukan oleh Maryeni dan kawan-kawan. (Maryeni; Rochmiyati; Sasmiati, 2014) dan Halimah (Halimah, 2015) tentang tingkat pemahaman guru terhadap Kurikulum 2013.

Berdasarkan analisis hasil wawancara, yang tinggi perannya terhadap pemahaman 
instrumental adalah aspek sikap personal, sikap pimpinan, pengetahuan dasar personal, regulasi sekolah, pendidikan dan pelatihan yang sistematis dan terjadwal, serta sistem pengawasan, monitoring dan evaluasi pekerjaan. Hal ini menunjukkan bahwa tingkat pemahaman instrumental guru lebih banyak dipengaruhi oleh faktor-faktor eksternal, yaitu faktor-faktor yang berada di luar kendali si guru yang bersangkutan.

\section{Kesimpulan}

Penelitian ini telah menemukan 6 (enam) hal pokok yaitu (1) tingkat pemahaman guru terhadap konsep pembelajaran aritmatikabahasa di SD ditinjau dari aspek pengetahuan menunjukkan kondisi yang cukup menggembirakan, $85 \%$ responden telah memiliki tingkat pemahaman yang baik; (2) pengetahuan responden terhadap aspek buku pembelajaran aritmatika-bahasa (calistung), hanya sekitar 39\% responden yang memiliki pemahaman yang cukup baik.; (3) pemahaman guru tentang kurikulum pembelajaran aritmatika-bahasa yang diperoleh melalui pelatihan sangat rendah, yakni hanya $13,33 \%$ responden yang memiliki pemahaman tinggi; (4) pemahaman responden terhadap proses pembelajaran cukup baik, yakni $75,55 \%$ responden memiliki pemahaman yang baik. Hasil tersebut sejalan dengan hasil penelitian Saniy (Saniy, 2014); (5) analisis komponen terhadap RPP menunjukkan bahwa pemahaman guru ada pada skor 53,45\%. Jika Angka ini jauh dari indikator minimal pemahaman yang ditetapkan yakni sebesar $76 \%$; (6) berdasarkan hasil observasi pembelajaran diketahui rata-rata skor guru hanya $23,22 \%$. Skor ini jauh dari indikator minimal yang ditetapkan sebesar $76 \%$.

Pada umumnya guru masih menggunakan model pembelajaran konvensional. Begitu pula pada aspek penilaian. Langkah penilaian yang dilakukan oleh guru masih berkisar pada penilaian akhir pembelajaran, dan bukan penilaian otentik.

Berdasarkan hasil penelitian ini perlu disampaikan rekomendasi sebagai berikut: (a)
Para guru pengampu mata pelajaran aritmatikabahasa perlu memperoleh pelatihan tambahan dengan forkus pada keterampilan mengajar menggunakan model pembelajaran terbaru. (b) Pihak-pihak terkait perlu melakukan monitoring dan evaluasi (monev) secara terus-menerus dan berkelanjutan terhadap pelaksanaan pembelajaran di SD kelas rendah, dengan mempertimbangkan aspek pembinaan sebagai hal penting dalam monev tersebut. (c) Rendahnya kualitas siswa di Indonesia merupakan akibat langsung dari rendahnya kualitas guru. Oleh karena itu kebijakan tentang mutu guru SD perlu menjadi perhatian serius pemerintah, utamanya dengan mengevaluasi guru-guru yang telah memperoleh tunjangan fungsional (tunjangan sertifikasi guru).

\section{Referensi}

Adriyani, \& Kuntarto, E. (2017). Etnomatematika: model baru, Jurnal Gantang, 2(2), 133-144. https://doi.org/10.31629/jg.v2i2.203

Ayuni, F. N. (2015). Pemahaman guru terhadap pendekatan saintifik (scientific approach) dalam pembelajaran geografi. JGea: Jurnal Pendidikan Geografi, 15(2), 1-7.

Halimah, S. (2015). Analisis pemahaman dan kesiapan guru mengimplementasikan kurikulum 2013. Medan: IAIN Sumatera Utara.

Harsono. (2005). Pemahaman guru propinsi jawa tengah terhadap kemampuan melihat kemampuan melihat dan bertanya tentang realitas dalam rangka penerapan metode pembelajaran ilmiah Oleh: Harsono (Staf Pengajar FKIP UMS), 38-61.

Kuntarto E. (2013). Pembelajaran calistung. (E. Kuntarto, Ed.) (1 Edition, Vol. 126). Jambi: Universitas Jambi. Retrieved from https://repository.unja.ac.id/cgi/users/home ?screen=EPrint $\% 3 \mathrm{~A} \% 3 \mathrm{AView} \&$ eprintid $=6$ 34

Kuntarto, E., \& Asyhar, R. (2016). Pengembangan model pembelajaran 
JURNAL GANTANG. September 2018; III(2): 97 - 108

p-ISSN. 2503-0671

e-ISSN. 2548-5547

blended learning pada aspek learning design dengan platform media sosial online sebagai, 1-26. Retrieved from https://repository.unja.ac.id/cgi/users/home ?screen $=$ EPrint $\% 3 \mathrm{~A} \% 3 \mathrm{AView} \&$ eprintid $=6$ 26

Kuntarto E., \& Destrinelli. (2014). Kajian implementasi kurikulum 2103 pada pembelajaran calistung di sekolah dasar. Jurnal Berkala PKIP Universitas Jambi, $1-$ 19. Retrieved from www.fkip.unja.ac.id/

Maryeni, Rochmiyati, Sasmiati. (2014). Analisis tingkat pemahaman guru sekolah dasar tentang pembelajaran terpadu pada kurikulum 2013, 1-11. Retrieved from http://download.portalgaruda.org/article.ph $\mathrm{p}$ ?article $=288730 \& \mathrm{val}=7239 \&$ title $=$ pemaha man guru sekolah dasar tentang pembelajaran terpadu pada kurikulum 2013

Saniy, M. M. A. (2014). Perbandingan prestasi belajar matematika siswa sd negeri sampangan 02 semarang yang mendapat calistung dan tidak mendapat calistung di taman kanak-kanak. Educational Psychology Journal, 3(1), 14-18. Retrieved from http://journal.unnes.ac.id/sju/index.php/epj

Wardhani, S. W., Hasyim, A., \& Rosidin, U. (2015). Evaluasi pembelajaran membaca, menulis, dan berhitung. Jurnal Teknologi Informasi Komunikasi Pendidikan, 2(5). Retrieved from http://jurnal.fkip.unila.ac.id/index.php/JTP/ article/view/6227

Zamzami, U., \& Yuniarni, D. (n.d.). Analisis tingkat pemahaman guru terhadap kegiatan pembelajaran pada taman kanak-kanak. Retrieved from http://jurnal.untan.ac.id/index.php/jpdpb/art icle/viewFile/20892/16992 